\title{
$\mathrm{X}$ 線顕微鏡で細胞内に何が見えるか？
}

清水 秀明 ${ }^{\circ}$ (香川大学), 眞島 利和(電総研), 富江 敏尚(電総研)

\section{What is Visible in Cells to X-ray Microscopy}

\author{
Hideaki SHIMIZU ${ }^{\bigcirc}$, Toshikazu MAJIMA and Toshihisa TOMIE
}

\begin{abstract}
$\mathrm{X}$-ray microscopy is promised to be a useful tool for studying living biological specimen without dehydration and fixation. A laboratory-sized x-ray microscopy system was realized as a flash contact microscopy using a laser-produced plasma as a flash $\mathrm{x}$-ray source. X-ray images of living biological specimens obtained by the system were provided. Some of these images indicate fragile structures in living states, which are damaged by dehydration of specimens.
\end{abstract}

Keywords: X-ray microscopy, cell, micro-structure, AFM

\section{1. 緒 論}

現在、細胞の微細構造を観察する方法として、電子顕 微鏡が使われることが多い。しかし, 電子線を使うため, 試料を真空中に保たなければならない。従って，試料の 固定脱水操作が不可欠である。さらに，電子線照射中の 試料損傷が大きい。コントラストを上げるため重金属染 色をおこなったり，金属などを蒸着することが多い．電 子顕微鏡での得られた画像の善し悪しは, 固定, 薄片化, 脱水, 染色などの操作で決まり，これらの過程での試料 の変形 (アーチファクト) には常に心しなければならな w.

[水の空] と呼ばれる $2.3-4.4 \mathrm{~nm}$ の波長域では, 生体の重要な構成物質である夕ンパク質や核酸の吸収 に比べて, 水の吸収は 1 桁小さい(Fig.1).したがって、 $X$ 線顕微鏡では、無固定で生きたままの観察が可能とな るため, 光学顕微鏡の低倍率, 電子顕微鏡での真空中観 測の欠点を補うものとして注目されている. 特に, 無固 定, 無染色, 高分解能と言う特長は, 生命活動を行って いるその瞬間をアーチファクトの心配をせずに観察で きることを意味し，大きい魅力である．

2. 密着型フラッシュX線顕微鏡システム

$\mathrm{X}$ 線顕微鏡には、結像型、走査型、投影型等々種々の 方式がある（1）。ここでは、筆者らが手掛けた密着型 フラッシュ顕微鏡（2）を紹介する。

われわれは、小型が可能なレーザープラズマから放射
されるX 線を線源とする研究室サイズ（テーブルトッ プ）の密着型X線顕微鏡を開発した（4).

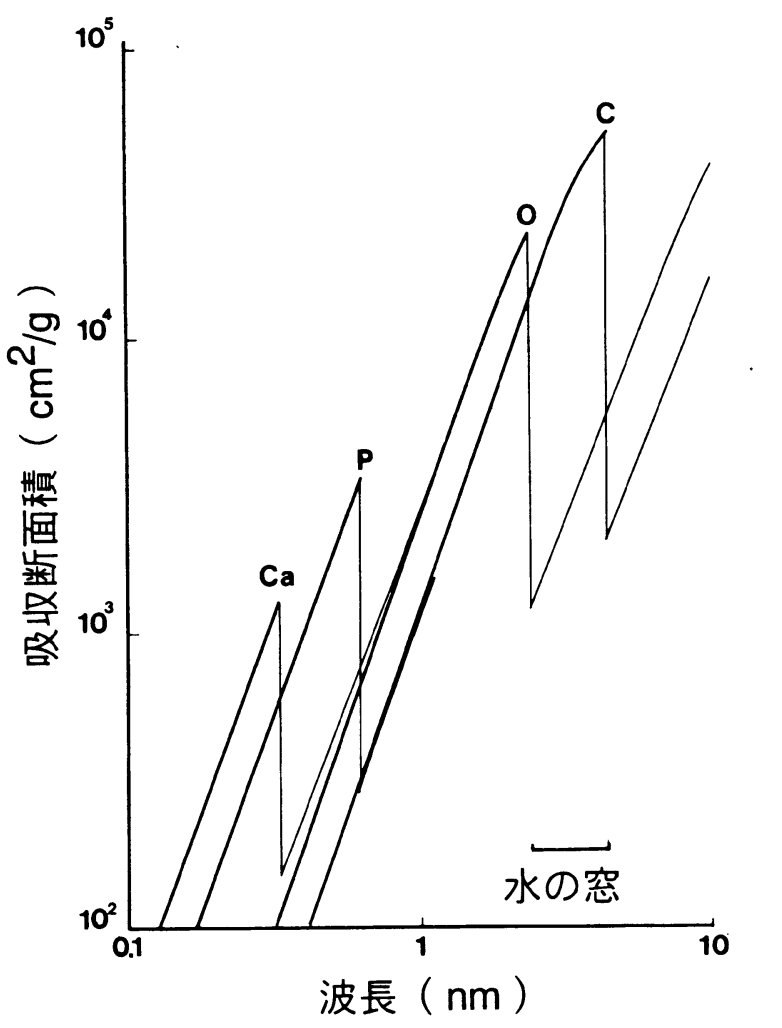

Fig.1: Absorption coefficient of representative elements composing cells near the $\mathrm{K}$ edges. 
密着型 X 線顕微鏡とは, X 線レジスト ( X 線感光材料) の上に試料を置き，X線による影絵を記録する方法であ る、レジストの現像後, 適当な別の方法でその影絵レリ ーフを読み取り可視化するものである。

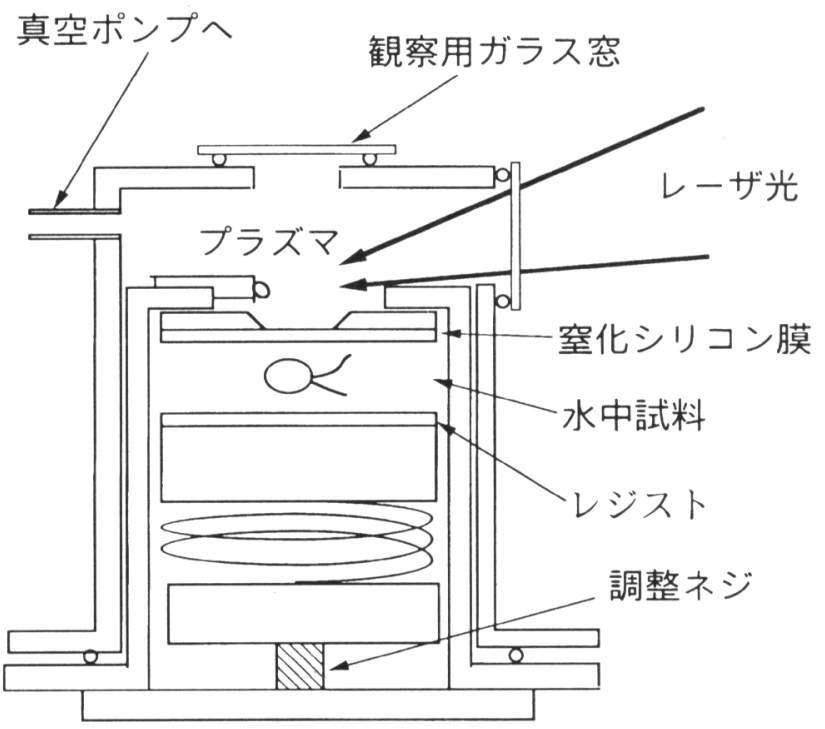

Fig.2: Schematic diagram of the $\mathrm{x}$-ray exposure apparatus of the contact $x$-ray microscope using a laser-plasma $x^{-r a y}$ source.

Fig.2にX線露光装置の模式図を示す。パルスレーザ 光 (波長： $0.53 \mu \mathrm{m}$, パルス幅: $0.5 \cdot 3 \mathrm{~ns}$ ) を, 夕 ーゲット（イットリウム）に照射しプラズマをつくる. このプラズマから発生するX 線を $\mathrm{X}$ 線空 $\left(\mathrm{Si}_{3} \mathrm{~N}_{4}\right.$, 厚 さ：0.1 $\mu \mathrm{m}$ ) を通して, 溶液中の試料に照射し, X線し ジスト（ポリメチルメタクリレート，PMMA，厚さ： $0.5 \mu \mathrm{m})$ に影絵をつくる.イットリウムプラズマから発 生するX線のパワーはほほ[水の空]波長域にある(3). プラズマが作られる場所は真空であるが，試料の入って いる照射チェンバー内は大気圧であることに注意して欲 しい。したがって，試料扔よびその周りの水分はそのま ま保たれている。X線密は, 真空と大気圧との境界であ ると共に，プラズマから飛来する粒子が直接レジスト面 を損傷することも防いでいる。

露光後, メチルイソブチルケトン（M I B K ）とイソ プロパノール（ＩＰ）の1：1 溶液で現像しレリーフを 作成する。得られたレリーフは試料の大きさそのもので あり、レリーフの高さに試料のX線吸収量が反映されて いる。だから，像を搪大する必要があり，さらにレリー フの高さを読み取れることが望ましい，光学顕微鏡以上 の分解能が必要なときには,レリーフ上に金属を蒝着し， 電子顕微鏡で観察されることが多い。しかし, 電子顕微 鏡でレリーフの高さを精度良く読み取ることは容易でな

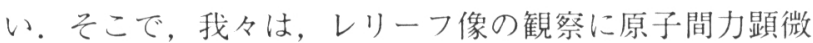
鏡（A F M ）を採用した。AFMを採用したため，蒸着 などの処理なしで,レリーフ形状が精度良く(一数 $\mathrm{nm}$ )
読み取れるようになった $(2)$. 以下示されるX線像は、 このようにして、可視化されたものである。

\section{3 。生物試料の X 線像}

\section{1 ウニの精子}

ウニ(ムラサキウ二) の精子は, 長さ約 $5 \mu \mathrm{m}$, 直径 約 $2 \mu \mathrm{m}$ の円錐状の頭部と, 太さ約 $0.2 \mu \mathrm{m}$, 長さ約 $40 \mu \mathrm{m}$ の鞭毛で構成される単細胞である。頭部には尖 体，核，ミトコンドリア（ドーナッッ状に鞭毛の起端を 取り巻いている）が主な構造として存在することがわか っている。鞭毛は，運動器官である軸系が細胞膜にくる まれている。

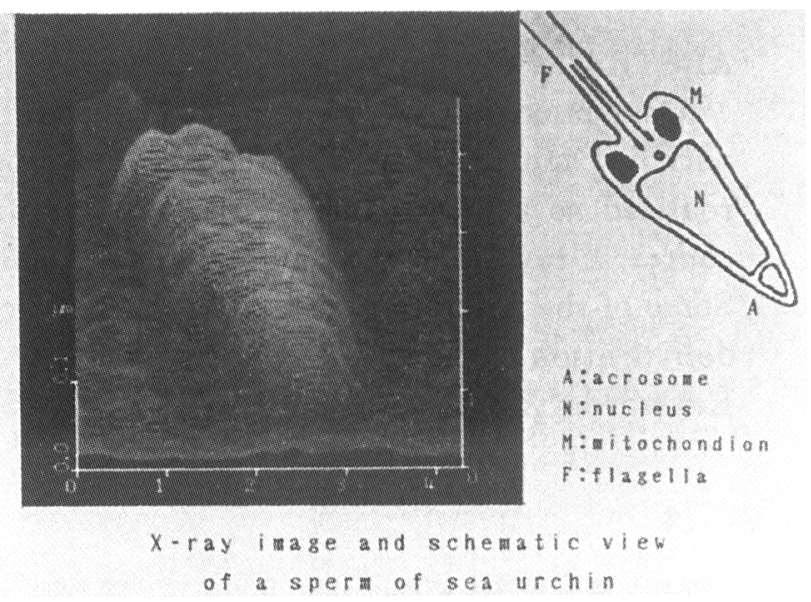

Fig. 3: Schematic drawing and $x$-ray image of sperm of sea urchin. Constriction of the image near the neck represents the interface of the nucleus and the mitocondrion. The dent at the neck corresponds to the doughnut shape of the mitocondrion.

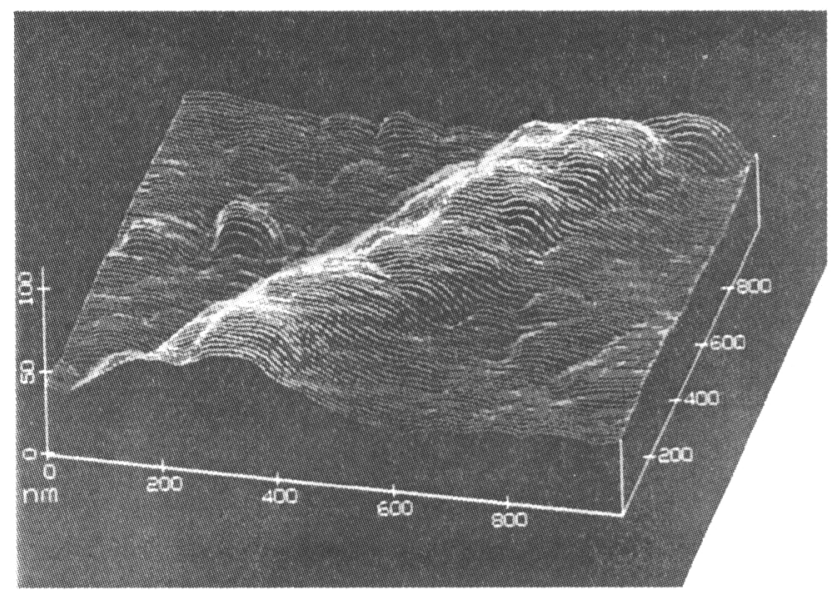

Fig. 4: X-ray image of a flagellum of sea urchin. A modulation in the width and height of a $0.2^{-}$to $0.4^{-} \mathrm{um}$ is seen.

Fig.3, Fig.4にX線像のA F M 読み取りの結果を示す. [水の空] の波長域のX線を使ったため, コントラスト を低下させる周りの海水の影響は非常に少ないことがわ 
かる.Fig.3 では、核とミトコンドリアの境界が明瞭に 確認でき,さらにミトコンドリアのドーナッッ状の様相 も確認できる。Fig.4に見られるように、鞭毛の太さは

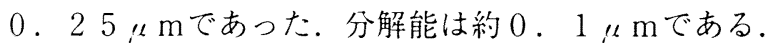
鞭毛の幅と高さに0。2ー0４《思のピッチのうねり が見えたが，この由来は不明である。今までの光学顕微 鏡観察, 電子顕微鏡観察のなかで直接対応するものはな い.しかし，鞭毛の細胞膜には柔軟性があり，さらに細 胞膜が内部の軸系との接続部を持つので，うねりのピッ チは軸糸へのピン止めのピッチに対応する可能性がある.

\section{2イモリの精子}

イモリの精子は、一本のわりと太い軸、運動を司る軸系、 およびそれらを結びつけている膜とで構成されている。 Fig. 5 にイモリの精子の像を示す。左側の図は、水中で のX線像である。右側の図は、走査型の電子顕微鏡によ る像である。ただし、水や、アルコールなどの表面張力 から膜様構造を守るため、固定処理をした後、炭酸ガス による臨界点乾燥を行っている。一見してわかるように、 軸の周りの膜様構造がそっくり同じように写っている。 このことは、X線像が試料に忠実であるということを意 味し、逆に、X線像により、電子顕微鏡用の固定・乾燥 処理の評価ができることを意味している。
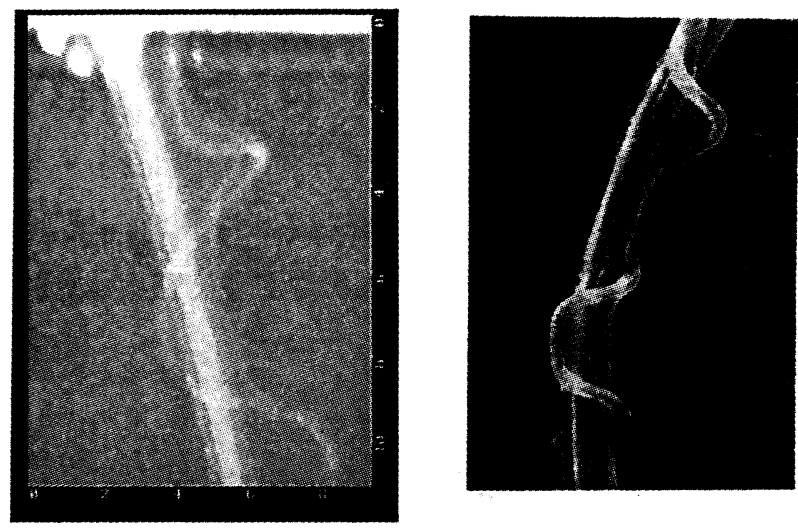

Fig. 5: X-ray image (left) and Electron microscopy image (right) of sperm of newt.

\section{3 フジツボの精子}

Fig.6 にフジツボ精子のX 線像を示す。フジッボの精 子は、ウ二の精子、イモリの精子とも違った形態をして いるが、精子運動を引き起こす鞭毛構造は。共通してい る。この像では、精子を包んでいる生体膜が破損し、鞭 毛を構成する軸䒺の構造が壊されて、ダブレット微小管 が露出し、広がっている様子が見られる。個々のダブレ ット微小管が識別できることからここでの分解能は、4 $0 \mathrm{n} \mathrm{m}$ 程度と思われる。

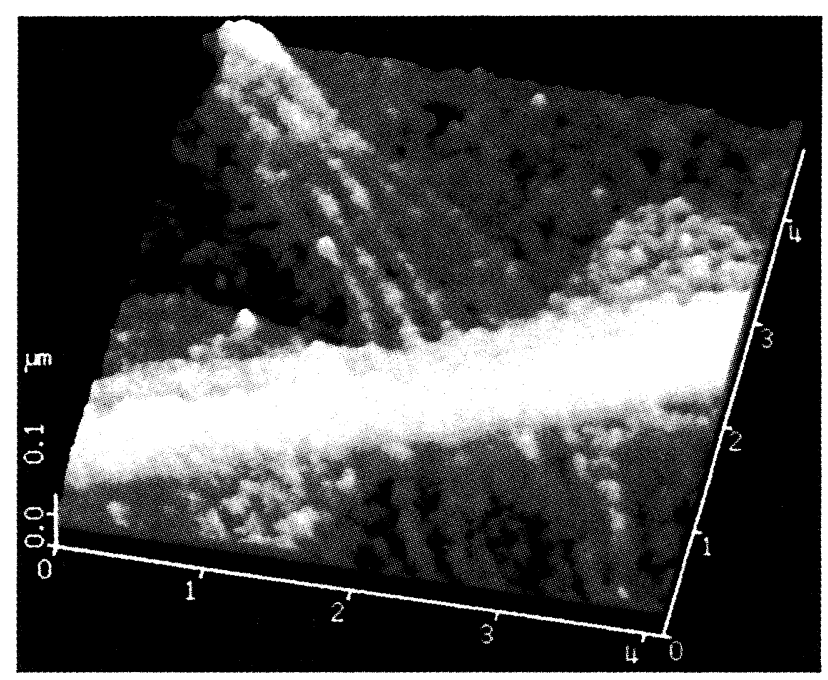

Fig. 6: X-ray image of sperm of barnacle. The doublet microtubules of the damaged sperm happened to spread out.

\section{4 クラミドモナス}

緑藻類の単細胞生物であるクラミドモナスの細胞体の X線像を Fig7 に示す。細胞体の周囲に、密度の低い領 域が見られる。この部分は、細胞壁とその周辺に相当す ると思われるが、固定された試料の電子顕微鏡観察では このような幅の構造は確認できていない。急速凍結した 試料のクライオ電子顕微鏡観察では、細胞膜に相当する 部分はかなりの厚みを持っていることが報告されている。 糖鎖を中心としたゲル状構造だと推定され、X 線顕微鏡 像は、従来の電子顕微鏡像より生きている状態に近いク ライオ電子顕微鏡像に対応していると考えられる。

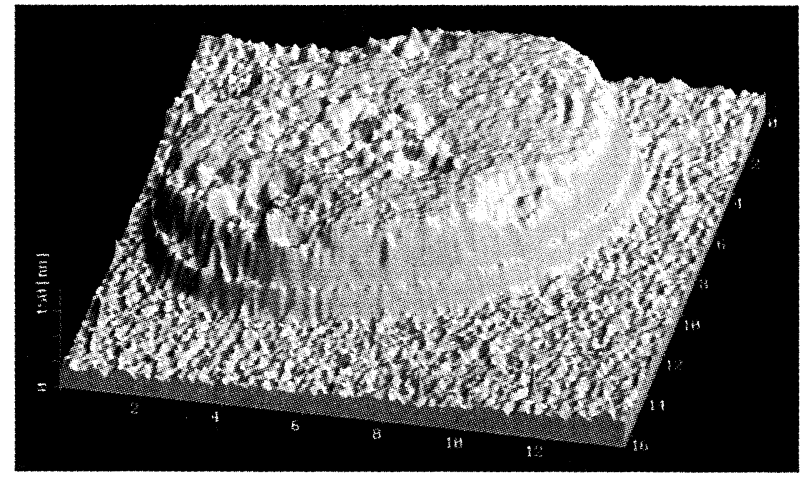

Fig. 7: X-ray image of chlamydomonas. It shows the existence of a low density envelope structure around the cell body.

\section{4.おわりに}

密着型のX線顕微鏡により、水中の生きたままの生物 試料の観察例を示した。X線露光され，現像されてえら れたレリーフ像の読みだしにA F M 世世界で初めて採用 することにより，試料の密度を定量的に議論できるよう になった。

分解能は 40-10 0 nm と見積られている.これは， 露光に関与するX線フォトン数の場所摇らぎに由来する 


\section{と思われる.}

現在のところ, フラッシュX線顕微鏡の分解能は電子 顕微鏡の分解能に遠く及ばないが, 既に光学顕微鏡の分 解能より優れている。なんと言っても、生きたままの状 態の試料の像が得られることが大きな特徴である。すで に、光学顕微鏡や電子顕微鏡では、観測しがたいもろい (壊れやすい) 膜構造や、ゲル状構造が観測され始めて いる。

さらに，現像されたレジストレリーフの高さを精度よく 読み出せれば，厚みのある試料内部の構造を推定できる ので, 分解能が $100 \mathrm{~nm}$ 程度でも, 新しい知見が得られ る可能性がある.熱吸収に伴う試料膨張は, 現在の場合, 問題になっていないが、さらなる高分解能を求めるとき には重要な問題となるであろう。照射X線の改良（大強 度化, 短パルス化) , レジスト処理技術の改良等によって, さらに分解能が向上すれば, 生物内部の微細構造をさぐ るのに有力な手段となると期待される.

\section{参考文献}

1）例えば M. R。・ハウエルズ，J，キルッ，D．七イヤー： “X線顕微鏡” 日経サイエンス， 21 卷 4 号， 34 (19 $91)$; 木原 裕: “X 線顕微鏡”、日本 ME 学会誌BME、 11 卷、 7 号、 37 ( 1997 ).

2) 清水秀明, 眞島利和, 富江敏尚, 金山敏彦, 近藤洋行, 山 田雅弘, 矢野雅昭: X線顕微鏡による生物観測, 電総研巢 報, 55 ， p. $819 ， 1991$; T. Tomie, H. Shimizu, T. Majima, M. Yamada, T. Kanayama, H. Kondo, M. Yano and M. Ono: "Three Dimensional Readout of Flash X-Ray Image of Living Sperm in Water by Atomic-Force Microscopy”, Science, 252, 691(1991).

3) H. Kondo and T. Tomie: "Optimization of a laser-plasma $x$-ray source for contact x-ray microscopy”, J. Appl. Phys., 75, 3798(1994).

4) H. Shimizu, T. Tomie, T. Majima, A. D. Stead, T. Ford, K. Miura, M. Yamada and T. Kanayama: "A Table-top Flash Contact X-ray Microscope", in "X-ray Microscopy and Spectroscopy" eds. by J. Theme, G. Schmahl, D. Rudolph and E. Umbach, Springer-Verlag Berlin/Heidelberg, I 157(1998). 